\title{
MONETARY COMPENSATION FOR UNFAIR DISMISSAL: A COMPARATIVE STUDY IN THE UNITED KINGDOM AND MALAYSIA
}

\author{
Siti Fazilah Abdul Shukor* \\ Asghar Ali Ali Mohamad** \\ Zuraini Abdul Hamid***
}

\begin{abstract}
Although unfair dismissal is not considered as a new issue in the current era, it may nevertheless severely affect the employees' right to earn a salary and other benefits such as retirement saving, among others. In order to recompense the employee's rights of employment, the legislature in many jurisdictions has introduced reinstatement as the remedy for unfair dismissal. Unfortunately, reinstatement is not awarded in most cases due to the long delay from the date of dismissal to the date of an award which may take a few years, where in the meantime the claimant may have comfortably settled in his new employment and in most cases would not desire reinstatement. Realising the above, the legislature has allowed the alternative remedy of monetary compensation for unfair dismissal. In fact, today, monetary compensation has become the remedy in both Malaysia and the United Kingdom. The Employment Rights Act 1996 of the United Kingdom recognises several remedies for unfair dismissal such as reinstatement, re-engagement, and monetary compensation. On the other hand, the Malaysian Industrial Relations Act 1967 merely provides reinstatement as the remedy for unfair dismissal; however, monetary compensation has been allowed vide the Industrial Court Practice Direction No. 1 of 1987, to be awarded at the discretion of the Industrial Court Chairman. In light of the above, this article discusses the awarding
\end{abstract}

\footnotetext{
* Postgraduate Student at Ahmad Ibrahim Kulliyyah of Law, International Islamic University Malaysia and Lecturer at Faculty of Business and Finance, University Tunku Abdul Rahman. Email: faziesha86@gmail.com .

*** Professor at the Civil Law Department, Ahmad Ibrahim Kulliyyah of Laws, International Islamic University of Malaysia. Email: ashgar@iium.edu.my . **** Assistant Professor at the Civil Law Department, Ahmad Ibrahim Kulliyyah of Laws, International Islamic University of Malaysia. Email: zurainihamid@iium.edu.my.
} 
of monetary compensation in the United Kingdom and Malaysia with reference to legislation and decided cases in the above jurisdictions.

Keywords: Monetary Compensation, calculation, unfair dismissal, United Kingdom, Malaysia

\title{
PAMPASAN KEWANGAN MERUPAKAN REMEDI UNTUK PEMBUANGAN KERJA SECARA TIDAK ADIL: KAJIAN DI UNITED KINGDOM DAN MALAYSIA
}

\begin{abstract}
ABSTRAK
Pada masa kini, pembuangan kerja secara tidak adil bukanlah satu fenomena baru yang melanda dunia. Namun ia mungkin akan menjejaskan hak pekerjaan pekerja seperti gaji, reputasi, manfaat kerja, pencen dan sebagainya. Selain itu, isu pembuangan kerja secara tidak adil juga menghalang hak pekerja sama ada secara langsung atau tidak langsung. Oleh itu, pihak berkuasa telah memperkenalkan remedi pengembalian semula untuk mengekalkan hak perkerja. Namun pada masa kini, pengembalian semula tidak dianugerahkan dalam kebanyakan kes disebabkan oleh beberapa masalah yang tidak dapat dielakkan. Oleh itu, pihak berkuasa membenarkan tuntutan pampasan kewangan sebagai remedi alternatif untuk kes-kes pembuangan kerja secara tidak adil. Selain itu, pampasan kewangan menjadi remedi terpenting dalam kedua-dua bidang kuasa (United Kingdom dan Malaysia) pada masa kini. Undangundang pekerjaan Inggeris (United Kingdom) telah mengiktiraf beberapa remedi untuk pemecatan yang tidak adil seperti pengembalian semula, penglibatan semula dan pampasan. Sebaliknya, Malaysia mengiktiraf pengembalian semula sebagai satu-satunya remedi manakala pampasan kewangan dianugerahkan atas budi bicara Presiden Mahkamah Perusahaan. Oleh itu, artikel ini membincangkan remedi yang digunapakai di United Kingdom dan Malaysia berdasarkan undang-undang statut. Selain itu, kajian ini menggunakan pendekatan kajian doktrin melalui pengkajian undang-undang statut dalam kedua-dua bidang kuasa serta menganalisis kepentingan mekanisme standad dalam pengiraan pampasan kewangan untuk kes-kes pembuangan secara tidak adil.
\end{abstract}

Kata Kunci: pampasan kewangan, pengiraan, pembuangan secara tidak adil, United Kingdom, Malaysia 


\section{INTRODUCTION}

Generally, employment law governs the relationship between the employer and the employee in an organisation besides according protection of employee's rights. When an employee's right is violated, or where there are any disputes in the employment relationship, the parties may resort to industrial relations law to resolve their disputes. An employee who has been deprived of his security of tenure is entitled to seek remedy in the Industrial Court. A successful claimant will be awarded monetary compensation with the intent to compensate him for any losses incurred as a result of his loss of employment. The amount to be awarded is generally at the discretion of the court based on the facts and circumstances on a case to case basis. Moreover, it is essential to ensure that the amount awarded is based on the substantial merit of the case, and the amount should not be excessive to the extent of financially burdening the employer. ${ }^{1}$ Therefore, it is appropriate to award monetary compensation, which is fair and adequate to an unfairly dismissed employee.

Prior to 2008, there was no specific provision regarding monetary compensation stipulated in the Industrial Relations Act 1967 (IRA 1967). The President of the Industrial Court, the late Harun Hashim, had introduced a mathematical formula for the calculation of the compensation vide the Practice Direction No. 1 of 1987. However, the inclusion of the Second Schedule in the IRA 1967 in 2008 indicates that the legislature indirectly acknowledges monetary compensation as one of the remedies for unfair dismissal. The inclusion of the Second Schedule was also intended to ensure that the Chairman ${ }^{2}$ of the Industrial Court complies with the requirements set therein. It is noteworthy that the Second Schedule has outlined several factors to be considered by the Industrial Court Chairman when assessing a fair and adequate monetary compensation.

Hence, this article is primarily aimed at formulating the guidelines for a fair assessment of monetary compensation, where the latter part of

\footnotetext{
${ }^{1}$ Asghar Ali Ali Mohamed, Dismissal from Employment and the Remedies $2^{\text {nd }}$ ed. (Malaysia: LexisNexis, 2014), 540.

2 Section 2 of the Industrial Relations Act 1967 defines "Chairman" as the Chairman of a division of the Court constituted under section 23.
} 
this article will show that the assessment guidelines in Malaysia are vague and too general. In this regard, it is necessary to compare Malaysian law with the practice in the United Kingdom due to the similar common law background. It will be observed that in the United Kingdom, the employees have better access to getting their rights enforced in the Employment Tribunal, ${ }^{3}$ where the guidelines on assessment are clearly provided in their employment statute. Many employees there are also governed by a collective agreement, which adequately sets the guidelines in the evaluation of the compensation. It is submitted that the decisions of the UK practice are necessary since the guidelines there are more transparent in the award of monetary compensation, which may be emulated and applied in Malaysia with essential modification to suit the circumstances here. Thus, this article will focus on the library-based method with reference to statutory law and case law on assessment guidelines adopted in the United Kingdom and Malaysia for unfair dismissal cases.

\section{THE PRACTICE OF MONETARY COMPENSATION IN MALAYSIA}

The practice of awarding monetary compensation is widely applied in industrial disputes. At common law, the only remedy for wrongful dismissal is monetary compensation, which is awarded to compensate the innocent party for breach of his employment contract. According to V. Anantaraman, there is no question of status or property rights once the contract is terminated, and the only concern is the issue of a civil claim for wrongful termination, to end the employment contract and the compensation awarded is to represent the loss of salary due to wrongful dismissal. ${ }^{4}$ Common law also imposes a duty on the employee to mitigate

\footnotetext{
${ }^{3}$ The Employment Tribunal is known as a tribunal or court to make decisions regarding any employment disputes in the United Kingdom.

${ }^{4}$ Venkatraman Anantaraman, Malaysian Industrial Relations: Law and Practice (Serdang: Universiti Putra Malaysia Press, 1997), 243-244.
} 
his losses by seeking alternative employment in the interim period pending the determination of his claim for wrongful dismissal. ${ }^{5}$

In Menon v The Brooklands (Selangor) Rubber Co. Ltd, ${ }^{6}$ Raja Azlan Shah FCJ (as His Lordship then was) stated that at common law the only remedy available to an employee is damages. He further noted that the criteria of emerging facts during the trial were essential to prove breach of contract, and the master/employer had to pay damages after the summary dismissal was unjustified. The remedy available at common law and under the employment statute is different, and this includes the assessment of monetary compensation.

In Malaysia, the law that governs unfair dismissal is the IRA 1967. This Act regulates the relationship between the employer and the employee in the private sector irrespective of whether they are local workers or migrant workers. ${ }^{7}$ According to the Universal Declaration of Human Rights 1948 (UDHR) and articles 5 and 8 of the Federal Constitution, all workers are equal before the law and are entitled to equal rights and protection. ${ }^{8}$ Moreover, the existence of employment statutes confers equal rights to both parties compared to common law. The existence of employment statutes has limited the absolute discretion of the employer to hire and fire the employee at common law. ${ }^{9}$ In Thilagavathy a/p Arunasalam and Maxis Mobile Service Sdn Bhd, ${ }^{10}$ the Industrial Court held that where the employee had contributed to his dismissal, the dismissal shall be deemed a fair dismissal or dismissal with just cause or excuse. In this case, based on the evidence adduced in the court, the employee had failed to obey the instruction of the superior, was unable to fulfil the job obligation and had breached the company policy, namely exiting the company WhatsApp group without the permission of

\footnotetext{
5 Anantaraman, Malaysian Industrial Relations: Law and Practice, 244; C.P. Mills, Industrial Disputes in Malaysia, $2^{\text {nd }}$ ed. (Kuala Lumpur: Malayan Law Journal, 1984), 133.

${ }^{6}$ (1968) 2 MLJ 186, (1968) 1 MLJ 15.

${ }^{7}$ Hamid, Z. A., Shukor, S. F. A. and Mohamad, A. A. A., "Rights of Migrant Workers under Malaysian Employment Law", Journal of East Asia and International Law 11, no. 2, (2018): 359.

${ }^{8}$ Ibid, pg. 359.

${ }^{9}$ Anantaraman, Malaysian Industrial Relations: Law and Practice.

${ }^{10}$ Award No: 1050 of 2019.
} 
the superior. Hence, the dismissal of the claimant was fair as the employee had contributed to her dismissal. In fact, the dismissal from employment was resorted to only after the employer had taken several other less severe measures, including issuing several warnings and counselling the employee for her indiscipline.

Under the IRA 1967, an employee alleging dismissal without just cause or excuse must seek reinstatement, which is the primary remedy under the Act. However, as previously noted, the commonly awarded remedy for successful unfair dismissal from employment is monetary compensation, thus making monetary compensation the preferred remedy. The granting of monetary compensation is subject to Section 30(6) of the IRA 1967. ${ }^{11}$ In Malaysia, the current practice of the Industrial Court is to award remedy of monetary compensation, the amount of which is based on the Chairman's discretion as well as subject to the facts and circumstances of each individual case. Generally, monetary compensation is divided into two parts, namely compensation in lieu of reinstatement and back wages. The former is to compensate the employee for loss of employment while the latter is to compensate the worker for losses incurred as a result of litigating the unfair dismissal claim. Those types of monetary compensation are payable by the employer upon the decision made by the Chairman based on the merits of the case.

The assessment of back wages is fixed at a maximum of 24 months, and other factors considered in determining the rate payable include the post-dismissal earnings and contributory conduct as stipulated in the Second Schedule. Also, Section 30(5) of the IRA 1967 confers on the Chairman the discretion to assess the appropriate amount as back wages. ${ }^{12}$ The Second Schedule of the IRA 1967 has laid out the general principle of monetary assessment, which is based on the abovementioned

\footnotetext{
${ }^{11}$ In making its award, the Court shall not be restricted to the specific relief claimed by the parties or to the demands made by the parties in the course of the trade dispute or in the matter of the reference to it under subsection 20(3) but may include in the award any matter or thing which it thinks necessary or expedient for the purpose of settling the trade dispute or the reference to it under subsection 20(3).

12 The Court shall act according to equity, good conscience and the substantial merits of the case without regard to technicalities and legal form.
} 
Practice Direction. ${ }^{13}$ Section 30(6A) provides that: "Notwithstanding subsection (6), the Court in making an award in relation to a reference to it under subsection 20(3) shall take into consideration the factors specified in the Second Schedule.' The Industrial Court is duty-bound to take into consideration the factors specified in Second Schedule which reads as follows:

"1. In the event that back wages are to be given, such back wages shall not exceed twenty-four months' back wages from the date of dismissal based on the last drawn salary of the person who has been dismissed without just cause or excuse;

2. In the case of a probationer who has been dismissed without just cause or excuse, any back wages given shall not exceed twelve months' back wages from the date of dismissal based on his last-drawn salary;

3. Where there are post-dismissal earnings, a percentage of such earnings, to be decided by the Court, shall be deducted from the back wages given;

4. Any relief given shall not include any compensation for loss of future earnings; and

5. Any relief given shall take into account contributory misconduct of the workman."

The abovementioned section denotes that the Chairman has to adhere strictly to the principle of assessing the monetary compensation in delivering the award. Further, the award of back wages should not exceed 24 months for permanent workers and not exceed 12 months for probationer workers. The calculation of back wages is subject to a few criteria such as post-dismissal earnings, loss of future earnings and contributory conduct. With the calculation method for deduction of back wages, the rights of the employer are also preserved. Further, the deduction of back wages due to contributory conduct can be considered as a punishment for the employee's disapproved conduct at the

${ }^{13}$ Practice Direction No.1 of 1987. Practice Direction is known as 'a note published by the authority of a court, judge, or other official bodies (sometimes under express statutory provision), usually indicating how procedures should be handled'. See Oxford English Dictionary, accessed February 13, 2019, https://en.oxforddictionaries.com/definition/us/practice_note. 
workplace. Whereas, the deduction of post-dismissal earnings is intended to encourage the employee to obtain new employment rather than remain idle while his claim under the IRA is pending in the Court. The Chairman has discretionary power to make an assessment according to the abovementioned guidelines. Indirectly, it allows the Chairman to deliver a fair and adequate award.

Moreover, there is no heading for the calculation of monetary compensation in lieu of reinstatement stipulated in the Second Schedule. Hence, the Chairman will follow the guidelines provided in the Practice Direction No. 1 of 1987 in awarding monetary compensation for those who are not eligible to be reinstated to his/ her former employment. The calculation of monetary compensation in lieu of reinstatement is based on the last drawn salary of the employee and multiplied with the number of years in employment. An employee whose service with the employer is less than 12 months will not be eligible for compensation in lieu of reinstatement. In a situation when the employee is dismissed during the probation period, the employer is required to pay the salary for the remaining months of probation. For example, the employee was employed under probation for six months, but the employee was dismissed on the third month of employment, where the dismissal was found to be an unfair dismissal based on the facts and evidence of the case; thus, the court will only award monetary compensation for the remaining three months of probation.

In the past, the court had awarded back wages that exceeded the maximum amount provided in the Practice Direction. This caused the employer to pay more than the required amount specified in the Practice Direction. This situation benefits the employee but indirectly causes financial hardship to the employer. This has therefore been another reason for the inclusion of the Second Schedule to avoid a flood of awards of excessive amounts of monetary compensation. Thus, the composition of the Second Schedule has limited the amount of monetary compensation by capping the maximum monetary award. However, the Second Schedule itself is not comprehensive enough to provide an accurate assessment. The IRA 1967 is silent on the types of 
compensation and the guiding principles of assessment compared to the United Kingdom. ${ }^{14}$

\section{THE METHODS OF MONETARY COMPENSATION APPLICABLE IN THE UNITED KINGDOM}

In the United Kingdom, the statutory rules that govern employment matters including the remedies of unfair dismissal are found in the Employment Rights Act 1996 (ERA 1996). Once a claim is brought to the tribunal under Section 111 of ERA 1996, the tribunal shall when determining the dismissal to be unfair make an order either to award reinstatement ${ }^{15}$ or order compensation. ${ }^{16}$ The Employment Tribunal should consider reinstatement first before deciding other remedies such as re-engagement ${ }^{17}$ and monetary compensation. ${ }^{18}$ This certainly strengthens the provision on reinstatement. ${ }^{19}$ If the Tribunal determines that reinstatement is impracticable for various reasons, it will then consider the possibility of re-engagement for the dismissed employee. ${ }^{20}$ However, the tribunal will not compel the employee to be reinstated if the employer is unwilling. In that situation, the tribunal will award compensation, i.e. the basic award or the compensatory award as stipulated in Section 118 of the ERA 1996. Hugh Collins, an

\footnotetext{
${ }^{14}$ Mohamed, Dismissal from Employment and the Remedies, 543.

15 Section 112 (3) of ERA 1996.

${ }^{16}$ Section 112 (4) of ERA 1996.

${ }^{17}$ Section 115 (1) of ERA 1996 stated that an order for re-engagement is an order, on such terms as the tribunal may decide, that the complainant be engaged by the employer, or by a successor of the employer or by an associated employer, in employment comparable to that from which he was dismissed or other suitable employment.

${ }^{18}$ Michael Bennett, "Montana's Employment Protection: A comparative critique of Montana's Wrongful Discharge from Employment Act in Light of the United Kingdom's Unfair Dismissal law", Montana Law Review 57, Issue 1, (Winter 1996): 138 .

${ }^{19}$ IT Smith and GH Thomas, Industrial Law, $8^{\text {th }}$ ed. (Butterworth: Lexis Nexis, 2003), 604.

${ }^{20}$ Barry I. Mordsley and Steven R. Wall, “The Dismissal of Employees under the Unfair Dismissal Law in the United Kingdom and Labor Arbitration Proceedings in the United States: The Parameters of Reasonableness and Just Cause", Cornell International Law Journal, 16, Issue 1 (Winter 1983): 42.
} 
employment law expert, stated that the monetary compensation in the United Kingdom is measured based on scale provided at common law and under the ERA. ${ }^{21} \mathrm{He}$ further stated that the compensation for unfair dismissal cases is usually measured based on common law and the assessment provided in the ERA is, in fact, based on common law practice. Further, the evaluation of monetary compensation under the ERA 1996 is to ensure a fair assessment for both employers and employees.

According to Bennett, the basic award attempts to value the employee's accrued service, and it can be calculated based on the age, the salary and the length of services. ${ }^{22}$ However, the compensatory award must act to compensate rather than to punish the employer for the financial loss or loss of benefit ${ }^{23}$ by the employee. The court should consider any contributory fault and mitigating factors in determining the compensation award. In the assessment of compensation, deduction shall be made for any payment already made to the employee such as the redundancy payment and payment of salary in lieu of notice. ${ }^{24}$ Generally, the system gives a clear picture in separating the compensation award and the practice of reducing the amount executed according to specific criteria.

In accordance with the ERA 1996, there is a section to determine the type of remedies for unfair dismissal. One of the remedies that are claimable with reference to ERA 1996 is monetary compensation. The calculation of monetary compensation is stipulated clearly in the ERA 1996. There are three types of monetary compensation claimable, namely basic award, compensatory award, and also additional award. The amount of basic award shall be calculated by taking into consideration the number of years in employment (not exceeding 20 years $^{25}$ ) with an appropriate amount. ${ }^{26}$ The assessment of an appropriate amount is

${ }^{21}$ Compensation for Dismissal: In Search of Principle, Industrial Law Journal 41, Issue 2, (2012): 208.

${ }^{22}$ Bennett, "Montana's Employment Protection", 138-139.

${ }^{23}$ Steven Anderman, The Law of Unfair Dismissal, $3^{\text {rd }}$ ed. (Butterworth: Lexis Nexis, 2001), 344.

${ }^{24}$ Bennett, "Montana's Employment Protection", 125.

${ }^{25}$ Section 119 (3) of ERA 1996.

${ }^{26}$ Section 119 (1) of ERA 1996. 
defined as follows: one and a half weeks' salary for each year of employment for employees aged between 41 and 64; one weeks' salary for each year of employment for employees aged between 22 and 41 ; and a half weeks' salary for each year of employment for employees aged below $22 .{ }^{27}$

According to Section 119(4) of ERA 1996, the stipulated termination of an employee after their $64^{\text {th }}$ birthday anniversary shall be deducted using an appropriate fraction ${ }^{28}$ from the total calculation. The amount of basic award before any reduction shall therefore not be less than $£ 2770{ }^{29}$ The reduction for the basic award is upon the tribunal's consideration based on the just and equitable principle. ${ }^{30}$ The tribunal will consider redundancy payment and the employees conduct before termination and refusal of the employee to accept an order from the tribunal. As stated earlier, the calculation of compensatory award is at the discretion of the tribunal based on the just and equitable principle, according to losses suffered by the employee due to the termination. ${ }^{31}$ The Tribunal should consider any factors such as losses suffered including any expenses incurred by the complainant due to dismissal, loss of any benefits expected to be received, loss of any entitlement or potential entitlement because of redundancy, and any loss sustained by the employee due to action taken by the employer. Also, any compensation or compensatory award shall not exceed $£ 11,300 .{ }^{32}$ In addition, an additional award will be granted based on the condition if the employer fails to comply with the re-employment order for any invalid reasons. ${ }^{33}$ Thus, the tribunal may award whatever amount which it considers fit and commensurate to the employee's loss caused by the non-compliance of the tribunal award as stated in Section 117(1) and 117(2) of the ERA 1996.

\footnotetext{
${ }^{27}$ Section 119 (2) of ERA 1996.

${ }^{28}$ Section 119 (5) of ERA 1996, the numerator is the number of whole months reckoned from 64 anniversary of the day of employee's birth in the period beginning with that anniversary and ending with the effective date of termination; and denominator is 12 .

${ }^{29}$ Section 120 of ERA 1996.

${ }^{30}$ Section 122 of ERA 1996.

${ }^{31}$ Section 123 of ERA 1996.

${ }^{32}$ Section 124 of ERA 1996.

${ }^{33}$ Robert Upek (2006). The law of Termination of Employment, $7^{\text {th }}$ ed. (United Kingdom: Jordan Publishing Limited, 2006), 392.
} 
The above explanation denotes that the ERA 1996 stipulates a detailed provision on the assessment of monetary compensation. Section 111 to Section 127 of the ERA 1996 provides a detailed discussion on monetary compensation under the heading of remedies for unfair dismissal. The Employment Tribunal will order these remedies based on the claims by the claimant as well as the shreds of evidence provided. Ultimately, the tribunal will focus on awarding reinstatement and reengagement as the primary remedy. It is only when reinstatement or reengagement is not practicable for several reasons would the Tribunal consider monetary compensation. In short, monetary compensation is provided as a remedy under the ERA 1996.

\section{THE ASSESSMENT OF MONETARY COMPENSATION IN THE UNITED KINGDOM AND MALAYSIA}

The UK and Malaysian jurisdictions show the types of monetary compensation awarded in unfair dismissal cases. Compensation remains as the prime remedy in unfair dismissal cases. The remedies for unfair dismissal in the United Kingdom look much more precise and detailed; however, in practice, the tribunal only tends to award monetary compensation similar to the Malaysian court. Indirectly, it indicates that both jurisdictions focus on the factors to be considered by the court or tribunal in awarding monetary compensation. However, there are differences in the calculation in both jurisdictions. The tribunal in the United Kingdom focuses on accurate assessment, while in Malaysia the calculation may be too general and vague as it is normally based on the Chairman's discretionary power besides considering the facts and circumstances of each individual case.

In spite of the above, there are similarities in both jurisdictions, namely the types of compensation awarded in unfair dismissal. The first type of compensation is the basic award in the United Kingdom, and compensation in lieu of reinstatement in Malaysia, with the intent to compensate the employee for the loss of employment based on service rendered in the employment. The second type of compensation is the compensatory award in the United Kingdom, and back wages in Malaysia aims to compensate the employee's actual loss due to unfair dismissal. Although the objective of both jurisdictions aims to reward the employee's service and compensate for their injuries, the calculation for both jurisdictions has some differences. Both jurisdictions will award the 
compensation based on the tribunal's discretion by referring to the facts and evidence of the cases brought forward. However, the calculation used by the Industrial Court in Malaysia differs from the calculation used by the Tribunal in the United Kingdom.

As noted earlier, the calculation of basic award in the United Kingdom is divided into three categories. These categories are based on the employee's age, and the compensation to be paid differs for each age category. This indicates that the calculation is mainly focused on their age, after which the period of employment is multiplied with the compensation pay according to week. The motive of having the abovementioned calculation is to uphold equity among the three categories of employees according to their age. Rather than having an equal formula for basic award calculation, the statutory bodies emphasises the calculation formula based on the employee's age and their life condition, which allows the award paid to compensate the employee's needs in life. Thereafter, the Employment Tribunal will consider the factors that may justify the reduction from the amount of basic award, namely, redundancy payment, contributory conduct, and mitigation of loss as well as the refusal of the employer to obey the tribunal's order.

For example, in the cases of Galloway $v$ Barnet Enfield and Haringey Mental Health NHS Trust, ${ }^{34}$ Phoenix House Ltd $v$ Stockman, ${ }^{35}$ Upton-Hansen Architects Ltd v Ms X Gyftaki, ${ }^{36}$ Frith Accountants Ltd $v$ Law, ${ }^{37}$ Park Chinois Ltd and another $v$ Ozkara and another, ${ }^{38}$ Hare

34 [2010] EWCA Civ 1368; the basic award, calculated by way of a formula relating to his age and years in the employment of $£ 5,220$, and reduction of $80 \%$ from the full award. The tribunal fixed the reduced basic award to $£ 1,044.00$. ${ }^{35}$ [2016] UKEAT/0264/15/DM, EAT; Tribunal further concludes that given the terms of the statutory basic award contribution provisions it is just and equitable to further increase the basic award reduction by the same amount to a total of $30 \%$.

${ }^{36}$ UKEAT/0278/18/RN In respect of the unfair dismissal claim the basic award is agreed in the sum of $£ 1,956$. As to the compensatory award, I am going to award a sum equating to a full loss at $£ 725$ net per week for a period of forty weeks, being the sum of $£ 29,000$.

${ }^{37}$ UKEAT/0460/13/SM; For the financial finding in respect of the basic award which is made, a sum of $£ 2,150$ will be substituted by agreement and reduction of $40 \%$ for contributory conduct. 
Wines Ltd v Kaur and another, ${ }^{39}$ Mr I Burgin v First Essex Buses Ltd, ${ }^{40}$ and $\mathrm{Mr}$ A Small v Downend Taxsavers $L t d,{ }^{41}$ the Tribunal ordered a basic award to be paid by following the age and employment service formula. The calculation is however also subject to reduction due to the employee's conduct. The above standard calculation denotes that the tribunal emphasises the upholding of and maintaining the harmonious relationship between employer and employee as well as protecting the rights of both employers and employees. The calculation was arranged with the intention to give fair and uniform protection to both parties in industrial disputes. Most importantly, the monetary award should not cause any difficulties or financial burden to the other, and the calculation based on the age categories ensures fairness and protection of the employee's rights at the workplace.

In contrast, monetary compensation in lieu of reinstatement in Malaysia is calculated based on the employee's number of employment services multiplied by the employee's last drawn salary. The calculation does not specify any category of assessment according to age or salary. The assessment of compensation in lieu of reinstatement is not contained in the Second Schedule of the IRA 1967, but is based on the Practice Direction, which contains guidelines to calculate monetary compensation issued by the President of the Industrial Court in 1987. Further, there is no maximum number of years of employment stipulated in the Practice Direction. In practice, the compensation in lieu of reinstatement will be awarded when the Chairman of the Industrial Court considers that reinstatement would be inappropriate in an unfair dismissal claim. In other words, the payment of monetary compensation in lieu of

${ }^{38}$ UKEAT/0224/18/DA, UKEAT/0225/18/DA \& UKEAT/0017/19/DA; the tribunal awarded the maximum capped unfair dismissal award in the sum of $£ 80,399$ (a basic award of $£ 1,437$ and a compensatory award of $£ 78,962$ ).

39 [2019] EWCA Civ 216; The Claimant was entitled to 12 weeks' notice by virtue of her length of service; and that she was in fact only paid for one week and three days. As such, the Respondent breached her contract of employment. The judge made awards totalling £16,401.38.

${ }^{40}$ [2017] UKET 3200438/2015; the Tribunal awarded $£ 5,104.00$ as a basic award.

${ }^{41}$ [2019] UKET 1405313/2018 (11 July 2019); the tribunal awarded basic award of $£ 2,076.93$. 
reinstatement is considered as an alternative remedy to a reinstatement claim, and its aim is to compensate the employee for loss of employment.

It may be added that compensation in lieu of reinstatement is not available to an employee who has attained the retirement age. In other words, once the employee reaches the retirement age according to Section 4 of the Minimum Retirement Age Act 2012 (Act 753) (MRAA $2012)^{42}$ which is 60 years old, they will not be entitled to receive any monetary compensation in lieu of reinstatement. This is based on the decision of the Federal Court in Sabah Forest Industries Sdn Bhd v Industrial Court Malaysia \& Anor ${ }^{43}$ and Unilever (M) Holdings Sdn Bhd $v$ So Lai \& Anor. ${ }^{44}$ In this cases, the Federal Court held inter alia, that the workman was not entitled to compensation in lieu of reinstatement as the employee had passed his compulsory retirement age and hence, the Industrial Court fell into error for awarding monetary compensation in lieu of reinstatement for the workman who passed the retirement-age provided in Section 4 of the MRAA 2012.

In addition, the learned judge also defines retirement as a termination of a contract of service of an employee on the ground of age. ${ }^{45}$ Inferably from this case, an employee who has attained the retirement age is not entitled to continue in employment, a decision which was upheld in $O o n$ Inn Soo v Ng Corporation Sdn Bhd ${ }^{46}$ and Ganeson A/L Muniandy v Linde Malaysia Sdn Bhd. ${ }^{47}$ The employee may continue in employment if the employer rehires them under a separate contract after the mandatory retirement age which is specified in the MRAA 2012, as stated in Amir

42 The MRAA has three immediate consequences on employers and workers in Malaysia:

(a) An employer cannot retire an employee earlier than 60 years.

(b) This minimum retirement age applies both to men and women.

(c) An employee may also continue in employment past the age of 60 years.

(d) An employee may choose to retire earlier than 60 years of age provided it has been agreed upon in the contract of service or collective agreement.

43 [2014] 8 CLJ 876

44 [2015] 3 CLJ 900

45 Section 3 of the Minimum Retirement Age Act 2012.

46 Award No: 659 OF 2017; attained retirement age and not entitle for reinstatement.

47 Award No: 1052 of 2016; attained retirement age and not entitle for reinstatement. 
Bin Osman Dan 2 Perayu Yang Lain v Meor Hamzah (M) Sdn Bhd. ${ }^{48}$ Thus, it denotes that an employee who has been rehired after having passed his retirement is not accorded protection under the Second Schedule and Practice Direction of 1987. It is humbly submitted that the exclusion of protection to an employee who has passed the retirement age is unjust towards the employee.

Besides the above, the calculation of compensatory award in the United Kingdom covers the areas of immediate loss of wages, manner of dismissal, future loss of wages, loss of pension rights and loss of any protection in respect of unfair dismissal or redundancy. ${ }^{49}$ This calculation is subject to evidence adduced by the employee before the tribunal, and, the amount to be awarded by the tribunal must fulfil the realistic standard of employees. Even though the ERA 1996 has limited the compensatory award to $£ 11,300$, this amount was nevertheless raised to $£ 50,000$ in 1999. The median level of awards before 1999 has been below the permitted ceiling for the last two decades, which impacts both employers and employees. ${ }^{50}$

Also, it should be remembered that the compensatory award aims to reimburse the employee and not to punish the employer. ${ }^{51}$ In fact, the payment of the compensatory award is to compensate the losses suffered by the employee because of his unfair dismissal by the employer. Basically, the award is payable according to what the employee would have been entitled to receive during the employment period before his unfair dismissal, as shown in cases such as Upton-Hansen Architects Ltd v. Ms X Gyftaki, ${ }^{52}$ Park Chinois Ltd and another v Ozkara and another, ${ }^{53}$

\footnotetext{
${ }^{48}$ Award No: 119 of 2016; there is a separate contract of employment after the employee attained the retirement age.

${ }^{49}$ Norton Tool Co Ltd v Tewson (1972) EW Misc 1, (1972) ICR 501; Upek, The Law of Termination of Employment, 349.

50 Susan Corby, Unfair Dismissal disputes: A Comparative Study of Great Britain and New Zealand, Human Resource Management Journal 10, no.1, (2000): 87.

${ }^{51}$ Ian Smith \& Aaron Baker, Employment Law, $11^{\text {th }}$ ed. (Oxford: Oxford Press, 2013), 533.

${ }^{52} \mathrm{UKEAT} / 0278 / 18 / \mathrm{RN}$ In respect of the unfair dismissal claim, the basic award is agreed in the sum of $£ 1,956$. As to the compensatory award, I am going to award a sum equating to a full loss at $£ 725$ net per week for a period of forty weeks, being the sum of $£ 29,000$.
} 
Mr I Burgin v First Essex Buses Ltd ${ }^{54}$ and Shifferaw v Hudson Music Co $L t d .{ }^{55}$ The Tribunal will determine and order that the employee is entitled to receive the compensatory award for their loss due to unfair dismissal. The calculation of award is subject to evidence adduced by the parties during the hearing, and the tribunal may apply the calculation approach for pension loss with reference to Compensation for Loss of Pension Rights - Employment Tribunals.

In addition, payment under this heading does not cover any nonfinancial loss because it is difficult to be calculated due to its subjectivity. It is also noteworthy that the word "loss" in Section 123(1) of the ERA 1996 does not indicate or include non-pecuniary loss. ${ }^{56}$ The Tribunal has a duty to assess the evidence adduced by the disputing parties to ensure that the payment is fair. The Tribunal will not award compensatory award if there is no loss sustained by the employee.$^{57}$ However, the Tribunal may award aggravated damages for losses sustained by the employee such as injury to feelings as in the case of Mr I Burgin v First Essex Buses Ltd,$^{58}$ AA Solicitors Ltd (T/A AA Solicitors) \& Anorv Majid, ${ }^{59}$ and Olayemi $v$ Athena Medical Centre \& Anor. ${ }^{60}$ The award of aggravated

${ }^{53}$ UKEAT/0224/18/DA, UKEAT/0225/18/DA \& UKEAT/0017/19/DA; the tribunal awarded the maximum capped unfair dismissal award in the sum of $£ 80,399$ (a basic award of $£ 1,437$ and a compensatory award of $£ 78,962$ ).

54 [2017] UKET 3200438/2015; the Tribunal awarded £26,550.30 as compensatory award after taking into consideration all the factors such as pension losses, additional childcare expenses and the additional travel that the Claimant has to undertake in order to work.

${ }^{55}$ UKEAT/0294/15/DA; awarded compensatory award with certain limitation by referring Compensation for Loss of Pension Rights - Employment Tribunals. ${ }^{56}$ Dunnachie v Kingston upon Hull City Council (2004) ICR 1052, (2004) UKHL 36; Upek, The Law of Termination of Employment, 350.

${ }^{57}$ Upek, The Law of Termination of Employment, 350.

58 [2017] UKET 3200438/2015; the Tribunal awarded $£ 20,000$ for injury to feelings in racial discrimination + interest of $£ 1,600=£ 21,600.00$ as aggravated damages.

${ }^{59}$ UKEAT/0217/15/JOJ; Tribunal awarded $£ 14,000$ for injury to feelings in a sexual harassment case.

${ }^{60}$ UKEAT/0140/15/LA; The Claimant won her claim of sex discrimination, the ET finding that the Respondent had subjected to her to a campaign of harassment designed to intimidate, humiliate and drive her out of the medical practice where she worked. She was dismissed in August 2008 and diagnosed as 
damages is not awarded for any unfair dismissal cases, but somehow, it has been awarded for discrimination cases. Claimants who sustained losses such as injury to feelings were awarded aggravated damages for sexual, racial, disability and gender discrimination cases.

In short, the calculation of basic and compensatory award has been clearly provided in the ERA 1996, which indicates that compensation is one of the remedies claimable for unfair dismissal cases. The Tribunal is conferred discretionary power to decide the amount based on the just and equitable principle regardless of technicalities ${ }^{61}$. The Tribunal decides the appropriate amount of compensation based on the evidence besides considering other factors such as mitigation of loss, contributory conduct and the availability of immediate employment, among others. These factors are subject to changes according to the evidence produced. Undoubtedly, monetary compensation is becoming an essential remedy for unfair dismissal claims in the United Kingdom. It is intended to compensate the employee for the loss of employment, and the amount is determined based on what seems to be adequate and reasonable. The assessment provided in the ERA 1996 has safeguarded the benefits and rights of both parties in the employment relationship.

Aside from the above, the calculation of back wages in Malaysia is limited to a maximum of 24 months multiplied by the last drawn salary as stipulated in the Second Schedule. The Chairman is empowered to make a deduction from the back wages on a percentage basis due to the employee's contributory conduct, post-dismissal earning, or any redundancy payment received upon termination. The deduction in the form of a percentage will be decided based on the evidence adduced by the parties at the trial before the Industrial Court. Generally, the burden is on the employer to justify the dismissal to be with just cause or excuse unless the claim is for constructive dismissal, where the burden shall be on the employee. The monetary compensation to be awarded to a successful unfairly dismissed employee is only when reinstatement is not practicable for several reasons. The award of monetary compensation is decided by the Chairman of the Industrial Court following the provision

suffering from PTSD. The ET awarded Dr Olayemi ("Dr O") compensation for sex discrimination comprising of $£ 30,000$ for injury to feelings (including $£ 5,000$ for aggravated damages) and $£ 21,875$ for (psychiatric) personal injury. ${ }^{61}$ Smith \& Baker, Employment Law, 533. 
of Section 30(5) of the IRA $1967 .{ }^{62}$ Indirectly, this implies that the Chairman of the court is conferred with broad power to decide the cases. Undoubtedly, the conferment of this vast power to the Chairman may lead to inconsistency of the monetary awarded by different Chairmen. This inconsistency may take place because there are no standard guidelines provided in the Second Schedule.

For instance, in Kamal Bin Abg Abu Bakar and Bank Pertanian Malaysia Berhad, ${ }^{63}$ the Industrial Court awarded a maximum of 24 months back wages with a deduction of $40 \%$ as a post-dismissal earning because the employee had obtained gainful employment with a good salary. However, in Abdul Azim bin Hamudin and Pulai Springs Resort $S d n B h d,{ }^{64}$ the Industrial Court deducted three months' salary as a postdismissal earning because the claimant was remained unemployed despite unsuccessful attempts to secure new employment and the company did not challenge the claimant's unemployment status. Thus, the Court award 21 months as back wages after the deduction of the postdismissal earnings. Whereas, in Tan Ah Gek and Maritime Intelligence $S d n B h d,{ }^{65}$ the Industrial Court did not make any deduction of the back wages for post-dismissal earning even though the claimant was unemployed and the company had not doubted this. From the above discussion, it is worth noting that there is inconsistency in the percentages of deduction from the back wages awarded by the Industrial Court. In each case, the court delivered a different percentage of the deduction for post-dismissal earning. The Chairman made the calculations above in accordance to Section 30(6) of the IRA 1967.

In relation to deduction of back wages due to claimant's contributory conduct, reference may be made to several awards of the Industrial Court.

62 The Court shall act according to equity, good conscience and the substantial merits of the case without regard to technicalities and legal form.

63 Award No: 210/2018. See Industrial Court awards. Available at http://www.mp.gov.my/en/

64 Award No: 97/2018. See Industrial Court awards. Available at http://www.mp.gov.my/en/

65 Award No: 8/2018. See Industrial Court awards. Available at http://www.mp.gov.my/en/ 
In Adam Lau Chee Seng $v$ Ambience Lighting (M) Sdn Bhd, ${ }^{66}$ the Chairman awarded 24 months as back wages with a deduction of $50 \%$ from the contributory conduct of the employee, namely, for the act of insubordination. Again, in the case of Chan Kuo Feng $v$ Purina Petcare (M) $S d n B h d,{ }^{67}$ the Industrial Court had deducted $40 \%$ from the maximum back wages due to the contributory conduct of the employee for not attending company meetings as well as the claimant's improper interference with the company policy. Also, in Mohd Husni Bin Abd Halim $v$ Rapid Rail Sdn Bhd, ${ }^{68}$ the court deducted $30 \%$ due to contributory conduct for the failure of the claimant to perform his duties in operating the ticketing machine. From the above cases, it is noted that the deduction of back wages is inconsistent where the claimant's contributory conduct is concerned, although the grounds for dismissal seems about the same in those cases. The deduction of back wages is also based on the evidence, and the percentage of the deduction is calculated according to the discretion of the Chairman. Further, there is no standard calculation on the deduction for contributory conduct and post-dismissal earning.

The Second Schedule itself does not specify guidelines for assessing monetary compensation, and it only has a vague standard that must be viewed by the court when making a fair assessment of the monetary award. Similarly, the Chairman of the Industrial Court also does not specify any standard calculation in awarding monetary compensation, and this, to some extent, had led to inconsistency of the monetary award for unfair dismissal cases. It is humbly submitted that this aspect should be focused on by the Chairman in assessing the monetary compensation and the percentage to be deducted from the back wages.

In a nutshell, the above discussion shows the importance of having a standard guideline for the calculation of monetary compensation for unfair dismissal. The calculation should be formulated with a sense of balance for both employers and employees. Without a proper mode of

66 Award No: 1453 of 2010; 20111 ILR 320. See Industrial Court awards. Available at http://www.mp.gov.my/en/

67 (2016) 1 ILR 388. Award No. 50 of 2016. See Industrial Court awards. Available at http://www.mp.gov.my/en/

68 Award No. 227 of 2016. See Industrial Court awards. Available at http://www.mp.gov.my/en/ 
assessment, the possibility of prejudice is high, and it affects both the employers and employees. It should be remembered that the IRA 1967 was introduced with the aim to promote industrial harmony and peace between employers, employees and trade unions. Hence, in awarding a fair and just award as well as upholding industrial harmony, it is submitted that a standard guideline on the assessment of monetary compensation is essential to both parties. Also, it is intended to maintain a fair and adequate monetary compensation without burdening the employer with an excessive award.

\section{CONCLUSION}

Monetary compensation is the remedy for unfair dismissal cases in both Malaysia and the United Kingdom. In the United Kingdom, the compensatory award is clearly provided in the ERA 1996, where the assessment of compensation is clearly mentioned and is easy for a layperson to understand as the calculation is not too complicated. However, in Malaysia, there is no standard guideline for calculating or assessing monetary compensation. This is even truer when monetary compensation is not even an alternative remedy that is claimable by the employee under the IRA. In fact, this remedy has been excluded as one of the remedies available under the IRA 1967.

Therefore, the suggestion to amend the IRA 1967 in relation to the subject matter of the discussion herein is timely and necessary. The legislature should emphasise on protection of employees' rights during their employment period. It is therefore submitted that monetary compensation should be included as one of the remedies that are claimable by the employee, and it should be subject to the facts of the individual case. The inclusion will protect the employment rights of employees and will also protect the employer's rights. This inclusion is important because monetary compensation is, in fact, awarded in the majority of unfair dismissal cases in Malaysia. Aside from the above, standard calculation guidelines for the calculation of monetary compensation should be formulated precisely and, in this matter, Malaysia can consider the United Kingdom practice and method specified in the ERA 1996.

Further, the deduction of any payment or contributory conduct should be categorised according to the head of conduct and payment with 
the percentage of deduction from least to higher. The urgency to formulate the standard guidelines on the calculation of monetary compensation is required because of the presence of inconsistency of award made by the Chairman. The inconsistency occurs because of broad discretionary power and vague guidelines which allow the Chairman of the Industrial Court to decide based on the merit of the cases. With a standard calculation of monetary compensation in the IRA 1967, it will ensure and uphold the fundamental rights of employees and employers in industrial disputes. Further, the inclusion will also give justice to all workers, including those who were hired after having passed their retirement age.

It is also proposed that there should be another head of compensation, namely, non-pecuniary loss calculation for unfair dismissal. It cannot be disputed that many employees suffer emotional distress such as anger, injustice, and a sense of bitterness arising from the harsh and humiliating manner of their dismissal. ${ }^{69}$ The calculation of non-pecuniary losses should be based on the aspect of the unemployment period after unfair dismissal, which causes mental distress and depression to employees. Further, during the unemployment period, the mental distress suffered by the employees should be weighed for purposes of awarding the monetary compensation.

In short, this study shows the differences in the assessment of monetary compensation in Malaysia and the United Kingdom. Therefore, the proposal is hereby made to the relevant bodies in Malaysia to consider improving the existing mode of assessment with a more precise calculation guideline with a view of minimising the inconsistency in the assessment of the awards. With the proposed amendment to the current system, the employment rights of both employers and employees will be further protected.

${ }^{69}$ Smith \& Baker, Employment Law, 533. 